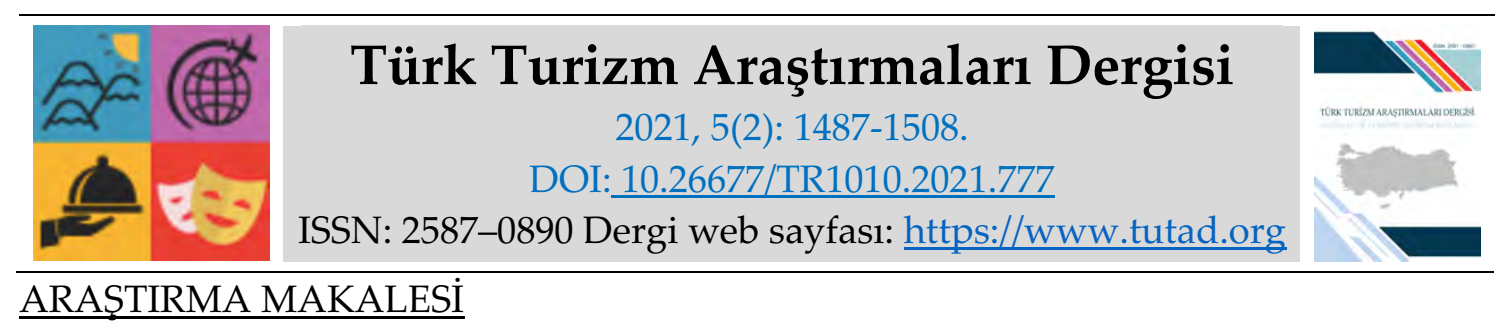

\title{
11 Eylül Saldırıları ve 2008 Ekonomik Krizi Örnekleri Üzerinden Terör ve Ekonomik Kriz Olgularının Yumuşak Güç Unsuru Olarak Turizme Etkileri*
}

Öğr. Gör. Dr. Çiğdem MUTLU, Dokuz Eylül Üniversitesi, İzmir Meslek Yüksekokulu, İzmir, eposta: cigdem.mutlu@deu.edu.tr ORCID: https://orcid.org/0000-0002-0033-4110

Prof. Dr. Zafer AKBAŞ, Düzce Üniversitesi, Akçakoca Bey Siyasal Bilgiler Fakültesi, Akçakoca, e-posta: zaferakbas@duzce.edu.tr ORCID: https://orcid.org/0000-0002-9974-5576

Öz

Turizm; esnek, heterojen özelliklere sahip hassas bir endüstridir ve dünyada yaşanan olaylardan olumlu veya olumsuz çok çabuk etkilenmektedir. Çalışmanın amacı, turizm ile, ekonomik krizler ve terör saldırıları arasındaki ilişkinin 11 Eylül 2001 terör saldırıları ve 2008 Ekonomik Krizi örnekleri üzerinden irdelenmesidir. Çalışmada, hassas niteliğe sahip turizmin hem terör saldırılarından hem de ekonomik krizlerden etkilendiği savunulmaktadır. Nitel araştırma modeli kullanılan bu çalışmada içerik analizi yöntemlerinden sıklık analizi kullanılmıştır. Çalışmanın evrenini, 11 Eylül 2001 terör saldırıları ve 2008 Ekonomik Krizi konularına hakim ve cevap verebilecek olan akademisyenler ile bu olgular hakkında görüş ve bilgiye sahip, turizm işletmelerinde şuan yönetici konumunda bulunanlar oluşturmaktadır. Çalışmanın örneklem büyüklüğü, maksimum çeşitlilik örnekleme stratejisi kullanılarak ve 30 katılımcı ile görüşülerek oluşturulmuştur. Çalışma sonucunda, terör ve ekonomik krizlerin turizm endüstrisini etkilediği ve olayların ölçeğine göre etki düzeylerinin değiştiği tespit edilmiştir.

*Bu çalışma Çiğdem MUTLU'nun ‘Terör ve Ekonomik Kriz Olgularının Yumuşak Güç Unsuru Olarak Turizme Etkileri: 11 Eylül Saldırıları ve 2008 Krizi Üzerinden Bir İnceleme' başlıklı doktora tezinden üretilmiştir.

Anahtar Kelimeler: Terör, 11 Eylül 2001 Saldırıları, 2008 Küresel Ekonomik Krizi, Yumuşak Güç, Turizm.

Makale Gönderme Tarihi: 15.02.2021

Makale Kabul Tarihi: 01.06.2021

Önerilen Atıf:

Mutlu, Ç. ve Akbaş, Z. (2021). 11 Eylül Saldırıları ve 2008 Ekonomik Krizi Örnekleri Üzerinden Terör ve Ekonomik Kriz Olgularının Yumuşak Güç Unsuru Olarak Turizme Etkileri, Türk Turizm Araştırmaları Dergisi, 5(2): 1487-1508.

(C) 2021 Türk Turizm Araştırmaları Dergisi. 


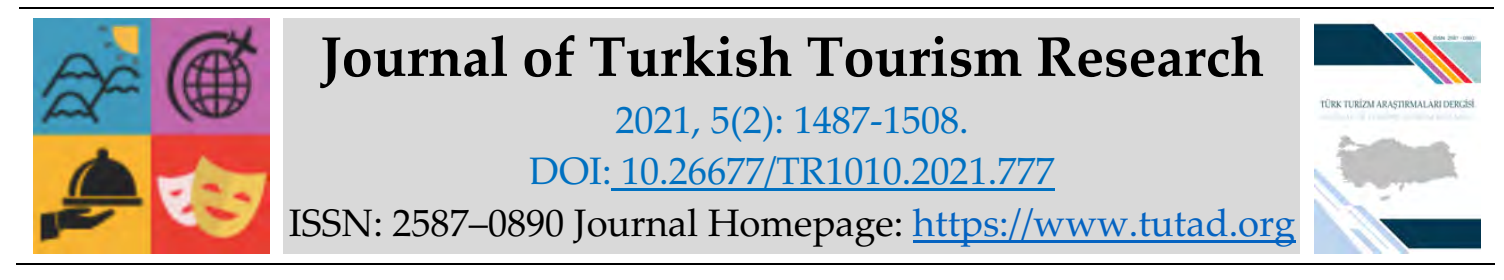

\title{
$\underline{\text { RESEARCH PAPER }}$
}

\section{Effects of Terrorism and Economical Crisis as A Matter of Soft Power on Tourism: An analysis Over The $11^{\text {th }}$ September Attact and 2008 Crisis}

Dr. Çiğdem MUTLU, Dokuz Eylül University, İzmir Vocational School, İzmir, e-mail: cigdem.mutlu@deu.edu.tr ORCID: https://orcid.org/0000-0002-0033-4110

Prof. Dr. Zafer AKBAŞ, Düzce University, Akçakoca Bey Faculty of Political Sciences, Akçakoca, e-mail: zaferakbas@duzce.edu.tr

ORCID: https://orcid.org/0000-0002-9974-5576

\begin{abstract}
Tourism having characteristics of flexibility, heterogeneity is a fragile industry. For this reason, it is affected by any positive or negative incident happening all over the world. The purpose of this study is to analyze the relationship of this fragile tourism industry with economic crisis and terror attacks through the examples of the September 11, 2001, attacks and 2008 Global Economic Crisis. In this study where qualitative research method used, frequency analysis method among content analysis methods have been applied. Target population of the study is composed of academicians who have the command and responsiveness of the September 11, 2001 terrorist attacks and the 2008 Economic Crisis, and those who have opinions and information about these phenomena and are currently managing tourism businesses. The sample magnitude of this study has been formed by using maximum sample survey strategy and interviewing 30 participants. As a result of the study, it has been determined that terrorism and economic crises affect the tourism industry and their effect levels change according to the scale of the events.
\end{abstract}

Keywords: Terror, the September 11, 2001 attacks, 2008 Global Economical Crisis, Soft Power, Tourism.

Received: 15.02 .2021

Accepted: 01.06.2021

\section{Suggested Citation:}

Mutlu, Ç. and Akbaş, Z. (2021). Effects of Terrorism and Economical Crisis as A Matter of Soft Power on Tourism: An analysis Over The $11^{\text {th }}$ September Attact and 2008 Crisis, Journal of Turkish Tourism Research, 5(2): 1487-1508.

(c) 2021 Türk Turizm Araştırmaları Dergisi. 


\section{Gíriş}

Turizm, sürekli olarak büyüyen ve gelişen endüstrilerden biridir. Küreselleşmenin bir sonucu olarak teknolojinin ilerlemesiyle birlikte turizm giderek güçlenmiş olup, ulusal ve uluslararası pazarda kendine önemli bir yer edinmiştir. Turizmin, politik, sosyo-kültürel, coğrafi birçok farklı unsurun birleşiminden oluşması, havayolu, seyahat, konaklama, gayrimenkul, yiyecek-içecek eğlence vb. birçok işletme ile ilişki içinde olduğunu göstermektedir. Bu boyutlar, turizmin son yıllarda uluslararası aktörler için yumuşak güç unsuru olarak önemi ve değerini giderek arttırmıştır. Bu bağlamda, yumuşak güç unsuru olarak turizm, uluslararası boyutta ortaya çıkan birçok endüstri kolunu etkileyen ekonomik kriz, terör, terörizm gibi olgulardan etkilenmektedir.

Bireyler, terör faaliyetlerinin gerçekleştiği veya potansiyel terör olaylarının olduğu yerleri ziyaretten kaçınmaktadırlar. Böylece, tercih edilmeyen turizm destinasyonları, özellikle ekonomik, sosyo-kültürel, güvenlik açısından risk taşıyan yerler olarak anılmaya başlamaktadır. Bu bağlamda, 11 Eylül 2001'de Amerika Birleşik Devletleri'nde (ABD) iki farklı hedefe yapılan saldırı da turizm hareketlerini olumsuz yönde etkilemiştir.

Turizmin, sadece sosyo-kültürel açıdan değil, özellikle talebin yüksek olduğu destinasyonları ekonomik olarak da geliştirdiği ve katkı sağladığı görülmektedir. 2008 yılında ABD'de başlayan ve hızlı bir şekilde yayılan ekonomik krizin, küreselleşmenin de etkisiyle, gelişmiş ve gelişmekte olan birçok ülkenin ticari faaliyetlerinin zayıflattığı tespit edilmiştir. Böylece, turizm taleplerinde görülen yavaşlama, turizm ekonomisinin de dengesini bozmuştur.

Çalışmanın amacı, küresel ölçekte gerçekleşen terör ve ekonomik krizlerin, hem uluslararası boyutların ortak kesişim noktası olması hem de yumuşak güç unsuru olması itibariyle, turizm endüstrisi üzerinde nasıl etkiler bıraktığı ve bu yansımaların hangi düzeyde olduğunun incelenmesi olarak tespit edilmiştir. Bu bağlamda, her iki unsurun turist sayılarının düşmesi, turizm gelirlerinin giderek azalması, güven duyulmayan destinasyonların tercih edilmemesi, turizm yatırımlarının azalması ve diğer sosyo-kültürel, ekonomik, politik vb. etkilerini, 11 Eylül 2001 saldırıları ve 2008 Ekonomik Krizi örnekleri üzerinden ortaya koymak bir diğer amaç olarak belirlenmiştir.

\section{Güç, Yumuşak Güç ve Turizm İlişkisi}

Güç kavramı, genellikle, baskı ve zor kullanarak istenileni elde etmeye çalışılması olarak algılanmasına rağmen, sadece bu anlama gelmemektedir. Gücün, aynı zamanda, farklı yöntemlerle zor kullanmadan amaç ve hedeflerine ulaşmak manası da taşıdığı bilinmektedir. Bununla birlikte, uluslararası ilişkilerde gücü öne çıaran teorinin realist teori olduğu belirtilmektedir. Fakat, güç kavramı, realist teoride olduğu gibi diğer teorilerde de devletlerin çıarlarına yönelik kullanılan bir araçtır (Akbaş ve Tuna, 2012: 7).

Güç, insanlar arasında olan bir ilişki şeklidir. Gücün ilişkilerindeki unsurlar aktör olarak adlandırılmaktadır ve bunlar; bireysel, grup, devlet, ulus devlet olabilmektedir. Aktörlerin gücünün temeli, birinin bir diğerinin davranışlarını etkilemeye ilave olarak fırsatlar, davranışlar gibi bütün kaynakları içermesiyle ilişkilidir (Dahl, 1957: 203). Güç kavramının, sert güç, yumuşak güç gibi çeşitleri vardır ve farklı şekillerde kullanılabilmektedir.

Güç kavramının farklı yöntem ve aracılar vasıtasıyla zor kullanmadan daha 1lımlı yollarla istenilen amaca veya hedefe ulaşılması anlamını taşıması turizm ile olan etkileşimini açık bir şekilde ortaya koymaktadır. Bu bağlamda, turizm yumuşak güç unsuru olarak değerlendirilebilmektedir. Yumuşak güç kavramı, ilk defa Joseph Nye tarafından, ülkelerin 
amaçlarına ulaşmak için, diğer aktörlerin tercihlerini cazip yöntemlerle şekillendirme yeteneği olarak ifade edilmiştir (Nye, 2004: 5).

Yumuşak güç kavramı, özellikle son yirmi yılda sürekli karşımıza çıkmaktadır. Yumuşak güç, bir ülkenin siyasi değerlerinin, politik amaçlarının ve dış politikada izlediği ilke ve yöntemlerin dışarıda doğurduğu cezbedicilik olarak ifade edilebilir. Yumuşak güç, en basit anlamıyla, bir ülkenin diğer ülkelerden askeri güç ve ekonomik zorlamalarla değil, amaçlarına ulaşmada sosyal, kültürel değerlerle çekicilik oluşturarak elde edebilme yeteneği olarak açıklanmaktadır (Gür, 2014: 2). Bununla birlikte, esas olarak, diğerlerinin bahsi geçen aktöre bakış ve yönelimini etkilemeyebilme kabiliyeti önemlidir. Bu kavram, aynı zamanda, akademik, bilim, kültür, müzik vb. dallarında da ülkeyi çekici duruma getirebilen bir niteliğe sahiptir (Kadercan, 2014: 315-316). Yumuşak güç kullanımını gerçekleştirebilen ülkeler, uluslararası alanda amaçlarına daha rahat ulaşabilmektedirler. Yumuşak gücün kaynakları, bir ülkenin değerleri (Almuedo, 2011: 11); iç ve dış devlet politikaları olarak açıklanabilmektedir. Ayrıca, bir devletin kültürü, tarihi, turizmi de yumuşak gücün temel unsurları arasında yer almaktadır (Nye, 2004: 17-20). Ancak, bu yumuşak güç kaynaklarına sahip olmalarına rağmen yeteri kadar kullanamamaları durumu da görülmektedir (Çavuş, 2012: 26-28-30).

Turizm ve yumuşak gücün birbiriyle olan ilişkisi en az dört yolla açıklanabilmektedir. Birincisi, turistlerin empati kurdukları yani beğendikleri destinasyonlar daha çok ve kolay gelişmektedir. İkincisi ise, turizm otoriteleri dünya üzerinde turizm açısından çekicilikleri olan ülkeler için imajları adına çalışma yaptırtmaktadır. Bir diğeri, olimpiyat oyunları gibi büyük etkinlikler jeopolitik etki oluşturmada önemlidir. Böylece, destinasyondaki turist sayısını arttırarak destinasyonu tanıtmaktadır. Son olarak ise, ülkesi dışına çıkan bireyler veya gruplar, gittikleri yerlere kendi ülkelerinin kültürlerini de beraberinde taşımaktadırlar (Ooi, 2015: 1).

Uluslararası ilişkilerde turizm, devletler için yumuşak gücü anlamak ve kullanımını arttırmak amaciyla başvurulan bir yöntemdir (Chen ve Duggan, 2016: 46). Bir ülkenin yumuşak gücünü kullanmasının farklı ve yeniliğe açık tarafları vardır. Çünkü, yumuşak güç ülkelerin, diğer ülkelerine kendilerine has niteliklerini yani kültürlerini tanıtmaları, aktarmalarıyla bağlı bir kavramdır. Böylece, diğer ülkeleri daha rahat etkileyebilmekte ve isteklerini elde edebilmektedirler (Gür, 2014: 2). Bu bağlamda, yumuşak gücün kullanımındaki cezbediciliğin oluşturulması, inandırıcılık, meşruiyet gibi unsurlarla tamamlandığında mümkün olacaktır. Bir ülkenin bu unsurlarla oluşturması gereken imaj ise bilgi çağında kullanılması gereken medya, internet gibi iletişim kaynaklarıyla bireylere ulaşabilmeleri gerekmektedir (Mor, 2006: 160).

\section{Kriz, Terör ve Turizm İlişkisi}

Devletlere ve uluslararası düzene bağlı olarak farklı birçok sebepten ötürü krizler ortaya çımaktadır. Bu krizler hem devleti hem de uluslararası düzeni tehdit edici niteliklere ulaşmıştır. Bununla birlikte, devletlerin uluslararası ilişkiler kurmaları, sürdürmeleri de krizlerin baskısı altında gerçekleşmektedir (Aydemir, 2005: 206). Kriz kavramı, aniden, beklenmedik ve tahmin edilemeyen bir zamanda ortaya çıkan durum olarak açıklanmaktadır (Roux ve Dufort, 2007: 107). Ayrıca, krizin önceden öngörülememesi, bilinememesi ve kolayca yayılması en önemli niteliklerindendir (Pusti, 2013: 1).

Terör saldırıları ve ekonomik krizler uluslararası düzeni bozan, tehdit eden, risk oluşturan önemli krizler arasında yer almaktadır. Terör ve terörizm, dönemlerin veya çağların değişmesiyle yenilenmektedir. Bu durum, terör ve terörizmle savaşmada yeni tedbirler alınmasını gerekli kılmaktadır. 11 Eylül 2001 saldırıları, kamuoyuna terör eylemlerinde tahmin edilemeyen yöntemlerin kullanıldığını veya kullanılabileceğini kanıtlayan en önemli örneklerdendir (Kutlu, 
2010: 1). Bununla birlikte, ekonomik krizler ise tüketici taleplerinin aşırı yükselmesi veya düşmesi ile bağlantılı olmakla birlikte, taleplerin artması ile devamlı ve yüksek oranlı enflasyon şeklinde ortaya çıkmaktadır (Yıldız ve Durgun, 2010: 1-2).

Ekonomik krizler, birçok endüstrinin gerilemesi, işsizlik problemleri, iş küçülmeleri, iflaslar vb. durumların ortaya çıkmasına neden olmaktadır. Dünya ekonomisini yönlendiren en önemli ekonomilerden biri olan ABD ekonomisinde ortaya çıan herhangi bir kriz dünya ekonomisini de etkileyecek niteliğe sahiptir. Bu nedenle, ABD'de ortaya çıkan ve daha sonra küresel bir boyuta ulaşan 2008 küresel ekonomik krizi neredeyse birçok dünya ülkesi ve ekonomisine negatif olarak yansımıştır (Yıldırım, 2010: 47-48). Buna istinaden, bütün dünyayı etkileyen bu krizlerin, ülkelerin, özellikle ekonomik açıdan yararlandığı turizm endüstrisini de etkilemesi kaçınılmazdır. Küresel finansal kriz ve ekonomik gerileme 2007'den 2010'a kadar turizmi etkilemiştir. Uluslararası turizm üzerinde, krizlerin potansiyel etkileri hem ölçek hem de sıklık olarak sürekli artış göstermiştir. Turizmde ekonomik ve finansal kriz oluşturacak etmenlerin çok iyi araştırılıp önlem alınması gerekmektedir. Aksi takdirde, bu krizlere bağlı olarak terörizm gibi diğer krizlerin de ortaya çıması olağandır (Hall, 2010: 401).

Turizm ve terörizmin, uluslararası niteliklere sahip olmaları, ulaşmak istedikleri kitleler ile bilgi teknolojilerindeki gelişmeleri kendi lehlerine kullanmaya çalışmaları gibi ortak yönleri bulunmaktadır. Ancak, her ikisi de birbirinden farklı ve zıt kavramlardır. Turizm, politik istikrar, ekonomik açıdan rahatlık vb. olguları kapsarken; terörizm ise tam tersi olguları (politik istikrarsızlık, talep ve gelir düşüklüğü vb.) içermektedir (Unur, 2000: 171). Bu bağlamda, terör saldırılarının gerçekleştiği destinasyonlar güvenlik, emniyet, barış vb. açılardan risk oluşturacaktır ve turistler kendilerini güvenli görmedikleri turizm bölgelerine seyahat etmeyeceklerdir.

Barış, güvenlik ve emniyet olguları, bir ülke, bölge veya destinasyonun turizm hareketlerinin gelişmesinde birincil faktörlerdir. Bu öğeler turizmin büyümesinin, öne çıkmasının temel belirleyicileridir (Cavlek, 2002: 478). Ayrıca, ABD'deki 11 Eylül 2001 yılındaki terör saldırılarının turizm üzerinde oldukça büyük etkisinin oluşu bu hassaslığa kanıt niteliğindedir (Blake ve Sinclair, 2003: 815).

Turizmde kriz olgusu yeni değildir, sadece tehdit algısı değişmiştir. Krizler, geçmiş dönemlerle karşılaştırıldığında daha güçlü etkilere sahiptir ve daha büyük bir popülasyonu etkilemektedir. Bu sebeple, turizmin fark edilebilir düzeydeki ekonomik değeri düşünüldüğünde, endüstride ortaya çıkan krizlere karşı aşırı duyarlı olması sürpriz değildir (Pforr ve Hosie, 2008: 250).

\section{Eylül Saldırıları ve 2008 Ekonomik Krizi ile Turizm İlişkisi}

11 Eylül terör saldırılarını düzenleyenler hedeflerini, ABD'nin ekonomik ve askeri güç unsurları olarak bilinen Dünya Ticaret Merkezi İkiz Kuleleri ve Pentagon olarak belirlemişlerdir. Böylece, daha önceden uluslararası sistem ürünü olan terör, bu saldırılar ile terör sistemlerini şekillendiren farklı bir şekle bürünmüştür (Ündücü, 2011: 13). 11 Eylül terör saldırılarıyla birlikte küresel terör başka bir niteliğe kavuşmuştur (Günal, 2004: 157).

11 Eylül 2001 saldırıları, ilk olarak Dünya Ticaret Merkezi kulelerini hedef alarak başlamıştır. ABD'de 19 saldırgan tarafından dört (4) Amerikan yolcu uçağı kaçırılmıştır (UN Security Council Resolution 1368, 2001: 1) ve Dünya Ticaret Merkezi'nin ikiz kulelerinden kuzey kulesine çarptırılarak saldırı başlatılmıştır. Bununla birlikte, kaçırılan ikinci uçak Dünya Ticaret Merkezi'nin güney kulesine (CNN U.S., 2001: 1) ve üu̧üncü uçak ABD'nin askeri güç merkezi olarak bilinen Pentagon binasına çarptırılmıştır. Son olarak kaçırılan dördüncü uçak ise; Pennsylvania eyaleti sınırlarındaki kırsal bir alanda düşürülmüştür (Sever ve Kılıç, 2001: 11-15). 
11 Eylül saldırılarının sonucunda yaklaşık 3000 kişinin öldüğü açıklanmıştır (UN Security Council Resolution 1368, 2001: 1).

11 Eylül 2001 terör saldırılarıyla birlikte yeniden şekillenen küresel terör, birçok ülkeyi ekonomik, siyasi, güvenlik, demokrasi, insan hakları vb. konularda derinden sarsmıştır. Böylece, 11 Eylül saldırıları, gelişen küresel terörün önemli bir göstergesi olmuştur (Kaplan ve Dayığlu, 2017: 623). 11 Eylül'deki terör saldırılarının ardından zaten zayıf olan uluslararası ekonomi giderek daha da düşüşe geçmiştir. Bu saldırılar sonrası yaşanan şok, anında turizm endüstrisinde, tüketici davranışlarında ve ABD'den çıkan yabancı sermayede fark edilmiştir (Nanto, 2001: 1-4).

11 Eylül terörist saldırıları diğer krizlerden daha büyük ölçüde dünyayı etkilemiştir. Bu saldırılarla birlikte, uçakla seyahat korkusu, belirsizlik ortamı, zayıf olan uluslararası ekonominin daha kötüye gitmesi ile tüketici ve yatırımlara olan güveninin düşmesi tüm dünyada tereddüt oluşturmuştur (UNWTO, 2001: 7). ABD'yi aşarak dünya tüm ülkelerine ulaşan bu saldırın sonuçları bireylerin can güvenliklerini düşünerek turizm aktivitelerine ara vermelerine neden olmuştur. Çünkü, turizm faaliyetlerine katılan kişilerin hareketlerini engelleyen bu gibi olumsuzlukların ortadan kalkması gerekmektedir (Mutlu ve Akbaş, 2016: 1-2).

11 Eylül saldırıları sonrası uluslararası turist sayıları ve turist gelirlerinin 2001 yılında düştüğü görülmektedir. 2000 yılında 686 milyon olan turist sayısı 2001 yılında 684 milyona düşmüştür. Aynı zamanda, 2000 yılında 475 milyar dolar olan uluslararası turizm gelirlerinin 2001 yılında 463 milyar dolara düştüğü belirlenmiş̧ir. Bununla birlikte, 2002 yılında, saldırıların hemen ardından, beklenilen düzeye gelmese de turizm verileri yavaş yavaş yükselmeye başlamıştır (https://www.e-unwto.org).

11 Eylül terör saldırıları dışında, küresel ölçekte yankı uyandıran ve turizm endüstrisini etkileyen bir diğer önemli olayın ise 2008 ekonomik krizi olduğu bilinmektedir (Yıldız ve Durgun, 2010: 12). Özellikle, krizlerin, tıpkı terör saldırılarında olduğu gibi, şiddetinin yüksek olması ülkelerin ekonomilerine daha büyük zarar vermesiyle sonuçlanmaktadır. 2008 yılındaki kriz, ABD'deki mortgage olarak bilinen ipotekli konut kredilerindeki sorun sonucunda patlak vermiş olan bir süreç olarak bilinmektedir (Apak, 2009: 13). 2007 yılının ortalarından itibaren kendini gösteren bu ekonomik kriz, bütün finans sektörünü de içerisine alarak uluslararası ölçeğe yayılmıştır (Durgun, 2010: 58).

Kredi ve emlak fiyatlarının birden artması, finansal düzenlemelerdeki zayıflıklar, yanlış fiyatlandırma gibi nedenlerle ekonomide kırılganlıklar ortaya çıkmıştır (IMF, 2010: 9). 2008 Ekonomik Krizi sonucunda likidite sorununun olduğu ve finansal kurumlara olan güvenin oldukça düştüğü belirtilmiştir (Kadıŏglu, 2010: 34-57). Bununla birlikte, dünya ölçeğinde işsizlik artışı, ekonomik daralma, büyümenin yavaşlaması, ödemeler dengesi ve ticari dengedeki olumsuz etkiler, doğrudan yabancı yatırım seviyesindeki küçülme, dünya ticaretinde daralma, turizmin gelirinin azalması gibi problemler de ortaya çıkmıştır (United Nations, 2009: 3). Ayrıca, bu krizden etkilenen endüstrilerin en başında konut piyasası yani gayrimenkul sektörü vardır ve ardından kamu sektörüyle hizmet sektörünü de etkilemiştir (Karaatlı, Demiral, Zeynel ve Pala, 2009: 146).

2008 yılında reel gayrisafi yurtiçi hasıla (GSYİH)'daki ciddi düşüşten sonra, 2009 yılı tahminleri dünya üretiminin daha düşük seviyelerde bir istikrara kavuştuğunu işaret etmesine rağmen, belirli bir süre zarfında, turizm endüstrisinde işsizliğin hala arttığı; döviz kurlarının hala dalgalandığı ve banka kredisi olanaklarındaki kısıtlamaların devam ettiği açıklanmıştır (Papatheodorou, Rossello ve Honggen, 2010: 39). 2008 küresel ekonomik krizi, turizm endüstrisi için ilk önemli kriz olarak bilinmektedir. Dünya üzerindeki uluslararası turist sayıları ve gelirlerinde ciddi boyutlarda azalmalar meydana gelmiştir (https://www.eunwto.org). 
2008 küresel ekonomik krizi ile birlikte, gelecek için maddi anlamda endişeler ortaya çıkmıştır. Bireyler, ya seyahatlerini ertelemiş veya daha uygun ucuz odalar tercih etmişler ve önceki yıllara oranla daha az seyahat etmişlerdir (Smeral, 2011: 17). Gelir düzeyi yüksek olan bireylerin, kriz döneminde pahalı olan konaklama işletmelerinin daha uygun fiyatlı hizmetlerinden satın almayı tercih ettikleri belirtilmiştir. Bunun sebebi olarak ise birçok insan aç ve evsiz kalırken bu tür ürünlere veya hizmetlere savurgan bir şekilde harcama yapmak sosyal olarak istenmediğinden kaynaklandığı gözlemlenmektedir (Pizam, 2009: 301). Bu bağlamda, bireylerin psikolojik açıdan etkilendikleri görülmüştür. Havayolu işletmeleri, 2008 yılının sonlarına doğru beklenilenden daha fazla kayıp olduğunu belirtmişlerdir (IATA, 2009: 11).

2008 küresel ekonomik krizin ardından turizm endüstrisi anında tepki vermiştir. Uluslararası turist sayıları 2007 yılında 911 milyon, 2008 yılında 930 milyon olarak hesaplanırken; 2009 yılında yaşanan düşüşle birlikte 893 milyon olarak gözlemlenmektedir. Bununla birlikte, 2007 yılında 896 milyar dolar olan uluslararası turizm gelirleri, 2008 yılında 968 milyar dolar olarak hesaplanmıştır. Ancak, 2008 Ekonomik Krizi ile birlikte, 2009 yılında bu rakam 881 milyar dolara düşmüştür (https://www.e-unwto.org).

Literatürdeki ampirik ve teorik çalışmalar ışığında, 11 Eylül 2001 saldırıları ve 2008 Ekonomik Krizi'nin de turizm endüstrisi üzerinde turizm talebi, turist sayısı, uluslararası turizm hareketleri ve diğer sosyal, kültürel, ekonomik, politik durumlardan olumsuz şekilde etkilendiği tespit edilmiştir. Sönmez, Apostolopoulos ve Tarlow (1999: 13) çalışmalarında, turizm endüstrisinin doğal ve insandan kaynaklanan durumlara karşı zayıf olduğunu belirtmiştir. Bununla birlikte, Mallison ve Mallison (1975: 36) çalışmasında terörü, şiddete yönelik tehditlerin düzenli ve sistematik bir şekilde kullanılması olarak açıklamıştır. Yıldırım (2010: 47-48), ABD ekonomisinin dünya ekonomisine yön veren en önemli ekonomilerden olduğunu ve $\mathrm{ABD}^{\prime}$ de meydana gelecek herhangi bir krizin dünya ekonomisini etkileyecek güce sahip olduğunu ifade etmiştir.

Turizm endüstrisi, 2008 küresel ekonomik krizinden diğer endüstrilerde olduğu gibi olumsuz yönde etkilenmiştir. Turizm işletmeleri arasında yer alan konaklama ve havayolu işletmeleri başta olmak üzere diğer turizm işletmeleri de bu krizden belirli oranlarda payını almıştır ve turist sayılarında düşüşler yaşanmıştır. Böylece, turizm işletmelerinin gelirlerinin azalması; işletmelerin kapanması veya yeni hizmetlerinin verilememesi sonucunu doğurmuştur. 2008 küresel ekonomik krizinin etkilerinin azaltılmasıyla beraber yeniden turizm iyileştirilmeye ve turist sayıları ile gelirleri arttırılmıştır. Ayrıca hem 11 Eylül saldırıları hem de 2008 Ekonomik Krizi'nin benzer sonuçları olduğu tespit edilmiştir.

\section{YÖNTEM}

11 Eylül 2001 terör saldırıları ve 2008 Ekonomik Krizi'nin, turizm endüstrisine olan etkilerinin her iki olguyu içine alarak ve kapsayarak bütüncül bir şekilde değerlendirilmesini sağlayacak alanında uzman kişi görüşlerinin önemi ortaya çıkmaktadır. Bu bağlamda, çalışmada, 11 Eylül 2001 terör saldırıları ve 2008 Ekonomik Krizi konularına hâkim ve cevap verebilecek olan akademisyenler ile bu olgular hakkında görüş ve bilgiye sahip turizm işletmelerinde şu an yönetici konumunda bulunanlar aracılığıyla objektif bir şekilde değerlendirmelerin yapılması ve irdelenmesinin mümkün olması nedeniyle araştırmada nitel araştırma modeli kullanılmıştır.

11 Eylül 2001 terör saldırıları ve 2008 Ekonomik Krizi konularına hakim ve cevap verebilecek olan bu iki gruptaki kişiler aracılığıyla küresel ölçekte hangi endüstrilerin etkilendiği, turizm endüstrisinin ne derece ve doğrultuda etkilendiğini, küresel açıdan sonuçları kapsamında boyutlar oluşturulmuştur. Bu boyutlar ile ilgili katılımcıların deneyimlerini, öngörülerini paylaşmaları araştırma problemine cevap oluşturacak nitelikte olduğu için önemli 
görülmektedir. Terör saldırısı ve ekonomik krizlerin yumuşak güç unsuru olan turizm endüstrisinin eski dönemlerde nasıl etkilediğini belirleyerek bu tip saldırıların yeniden yaşanması durumunda alınabilecek önlemlerin, ortaya çıkarılması doğrultusunda araştırma probleminin ortaya konulması amaçlanmaktadır. Bu kapsamda, araştırma problemi doğrultusunda oluşturulan alt problemlerin gerçekleri ortaya koyması ve mevcut şartlara anlam katabilmek amacıyla bu çalışmada nitel araştırma yaklaşımında fenomenoloji (olgubilim) araştırması olarak desenlenmiştir.

Çalışmanın temel amacına ulaşmak için kullanılan araştırmanın alt problemleri aşağıdaki gibi geliştirilmiştir;

1. Terör ve ekonomik kriz olgularının turizm endüstrisi üzerinde etkisi var mıdır?

2. 11 Eylül 2001 saldırıları ve 2008 Ekonomik Krizi sonucunda küresel ölçekte etkilenen endüstriler olmuş mudur?

3. 11 Eylül 2001 saldırılarının ve 2008 Ekonomik Krizi'nin ekonomik, sosyal, kültürel, psikolojik, politik açıdan küresel sonuçları olmuş mudur?

4. 11 Eylül 2001 saldırılarının ve 2008 Ekonomik Krizi küresel ölçekte turizm endüstrisine yönelik ekonomik, sosyal, kültürel, psikolojik, politik vb. açıdan sonuçları olmuş mudur?

\section{Evren- Örneklem}

Bu çalışmanın evrenini, 11 Eylül 2001 terör saldırıları ve 2008 Ekonomik Krizi konularına hâkim ve cevap verebilirliği olan akademisyenler ile bu olgular hakkında görüş ve bilgiye sahip, turizm işletmelerinde şu an yönetici konumunda bulunanlar oluşturmaktadır. Bu araştırmayı içeren evreni temsil edebilecek birimlerin spesifik özellikleri nedeniyle aynı konu hakkında farklı bakış açılarını ortaya koymak amacıyla maksimum çeşitlilik örnekleme stratejisi kullanılmıştır (Creswell, 2007: 127). Nitel araştırmalarda örneklem büyüklügünü belirlemenin oldukça zor olması ve çeşitli önerilere dayanması sebebiyle veri yeterliliğinin sağlanması, diğer bir ifadeyle elde edilen verilerin sıklıkla birbirini tekrarlaması durumu dikkate alınarak örneklem büyüklüğü oluşturulmuştur. Araştırmacı nitel araştırmalarda topladığı verilerin araştırma problemini cevaplamaya karşıladığına inandığı anda veri toplama ve örnekleme sürecini bitirebilmektedir (Akturan, 2013: 203). Bu bağlamda, 30 katılımcı ile görüşülerek örneklem büyüklüğü oluşturulmuştur.

\section{Veri Toplama Araçları}

Çalışma konusu ile ilgili uzman kişilerden ayrıntılı, gizil bilgileri açığa çıkartacak sorular sorarak konu ile ilgili detaylı bilgilere ulaşabilmek amacıyla görüşme tekniği kullanılmıştır (Aziz, 2011: 86). Görüşmeler, örneklem kapsamına giren paydaşlardan daha önceden randevu alınarak ve paydaşlara uygun olan tarih ve saatlerde gerçekleştirilmiştir. Ayrıca, görüşmeler, görüşmecilerin çalışma ortamlarında ve ulaşım, maliyet vb. kısıtlar sebebiyle görüşmeciler tarafından istenildiğinde internet üzerinden görüntülü görüşme ile gerçekleştirilmiştir. Görüşmeler yaklaşık 30-40 dakika arasında sürmüş olup; 1 Ağustos 2018 ve 1 Mart 2019 tarihleri arasında gerçekleştirilmiştir.

\section{Verilerin Analizi}

Nitel araştırmada veri analizi, analiz yapmak amacıyla verilerin hazır hale getirilmesi ve düzenlenmesi gerekmektedir. Bu aşamadan sonra veriler kodlanmaktadır ve bu kodlar 
birleştirilerek temalara indirgenmektedir. Temalar oluşturma aşamasından sonra ise verilerin tablolar haline getirilerek irdelenmesini kapsamaktadır (Creswell, 2007: 148). Bu doğrultuda, elde edilen veriler, kodlamalar ve kodlamalar sonucunda oluşan temaların tablolaştırılması ile analiz edilmiştir. Veri analizi sürecinde içerik analizi yöntemlerinden sıklık analizinden faydalanılmıştır.

\section{BULGULAR}

Araştırma çerçevesinde katılımcılara dört alt probleme ilişkin sorular sorulmuştur. Elde edilen verilerden yola çıkılarak derinlemesine bir inceleme yapmak amacıyla benzer özelliklere sahip bilgiler kodlanarak kendi içlerinde sınıflandırılmış ve araştırma amacına ilişkin yapılar oluşturulmuştur. Oluşturulan bu yapılar sıklık analizi aracılı̆̆ıyla tablolar oluşturularak aktarılmıştır.

\section{Katılımcılar ile İlgili Demografik Bilgiler}

Katılımcılara ait bilgiler Tablo 1'de verilmiştir. Katılımcılara görüşme sırasına göre K1, K2, K3 ... K30 olarak kodlama yapılmıştır. Bu doğrultuda katılımcıların yeterliklerine ilişkin temel bilgiler de Tablo 1'de yer almaktadır.

Tablo 1. Katılımcılara İlişkin Bilgiler

\begin{tabular}{|c|c|c|}
\hline Katılımcı Kodu & Katılımcılar & Alan \\
\hline K1 & Otel Yöneticisi & Turizm \\
\hline K2 & Akademisyen & Turizm \\
\hline K3 & Akademisyen & Turizm \\
\hline K4 & Akademisyen & Uluslararası İlişkiler \\
\hline K5 & Otel Yöneticisi & Turizm \\
\hline K6 & Otel Yöneticisi & Turizm \\
\hline K7 & Seyahat Acentası Yöneticisi & Turizm \\
\hline K8 & Yiyecek-İçecek İşletmesi Yöneticisi & Turizm \\
\hline K9 & Akademisyen & Turizm \\
\hline K10 & Seyahat Acentası Yöneticisi & Turizm \\
\hline K11 & Yiyecek-İçecek İşletmesi Yöneticisi & Turizm \\
\hline K12 & Seyahat Acentası Yöneticisi & Turizm \\
\hline K13 & Akademisyen & Uluslararası İlişkiler \\
\hline K14 & Akademisyen & Uluslararası İlişkiler \\
\hline K15 & Akademisyen & Uluslararası İlişkiler \\
\hline K16 & Akademisyen & Uluslararası İlişkiler \\
\hline K17 & Akademisyen & Sivil Hava Ulaştırma \\
\hline K18 & Akademisyen & Turizm \\
\hline K19 & Yiyecek-İçecek İşletmesi Yöneticisi & Turizm \\
\hline K20 & Otel Yöneticisi & Turizm \\
\hline K21 & Otel Yöneticisi & Turizm \\
\hline K22 & Akademisyen & Uluslararası İlişkiler \\
\hline K23 & Akademisyen & Turizm \\
\hline K24 & Akademisyen & Uluslararası İlişkiler \\
\hline K25 & Akademisyen & Turizm \\
\hline K26 & Yiyecek-İçecek İşletmesi Yöneticisi & Turizm \\
\hline K27 & Akademisyen & Turizm \\
\hline K28 & Akademisyen & Uluslararası İlişkiler \\
\hline K29 & Akademisyen & Uluslararası İlişkiler \\
\hline K30 & Akademisyen & Turizm \\
\hline
\end{tabular}


Tablo 1'e göre, araştırma konusu ile ilgili yeterli bilgiye ve cevap verebilirliğe sahip olan turizm işletmeleri yöneticileri ve akademisyenlerden katılımcllar ile görüşmeler yürütülmüştür.

\section{Terör ve Ekonomik Krizin Turizm Üzerinde Etkileri}

Küresel ölçekte, birçok endüstriyi çeşitli yönlerden etkileyen terör ve ekonomik kriz olgularının, özellikle hassas bir endüstri olan turizmi nasıl etkilediğine ilişkin görüşlerini aktaran katılımcı verileri Tablo 2'de incelenmiştir. Bu alt problemde kodlamalar aracılığıyla temalar oluşturularak bu temalara ilişkin görüşler ve görüş sıklıkları belirli özelliklere göre gruplandırılarak sinıflandırılacaktır.

Tablo 2. Terör ve Ekonomik Kriz Olgularının Turizm Üzerindeki Etkisine İlişkin Görüşler

\begin{tabular}{|c|c|c|}
\hline Tema & Kodlama & Kodların Sıklığı \\
\hline \multirow{4}{*}{ 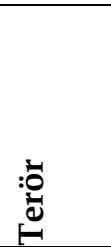 } & Turizm Talebini Olumsuz Etkiler. & 30 \\
\hline & $\begin{array}{l}\text { Turizm Endüstrisine Yapılan Yabancı Yatırımı Olumsuz } \\
\text { Etkiler. }\end{array}$ & 18 \\
\hline & Turizm Endüstrisindeki İstihdamı Olumsuz Etkiler. & 30 \\
\hline & Yerelden Küresele Etkiler. & 30 \\
\hline \multirow{6}{*}{ 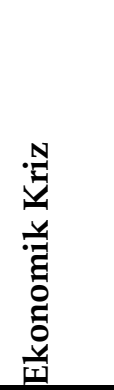 } & $\begin{array}{l}\text { Yaşanan Ekonomik Krizler Ülke Ekonomilerini Olumsuz } \\
\text { Etkiler. }\end{array}$ & 30 \\
\hline & Turistlerin Gelirlerinde Düşüş Yaşanır. & 20 \\
\hline & Turizm Endüstrisindeki İstihdamı Olumsuz Etkiler. & 25 \\
\hline & Turizm Endüstrisindeki Hizmet Kalitesini Olumsuz Etkiler. & 25 \\
\hline & $\begin{array}{l}\text { Turizmde Endüstrisindeki İşletmeler Küçülmeye Gitmek } \\
\text { Durumunda Kalabilir. }\end{array}$ & 10 \\
\hline & Turizm Endüstrisinde Yapılacak Yatırımları Olumsuz Etkiler. & 13 \\
\hline
\end{tabular}

Tablo 2'ye göre katılımcıların terör ve ekonomik kriz olgularının turizm endüstrisi üzerindeki etkisini değerlendirdiği görülmektedir. Buna göre, katılımcıların hepsi terör saldırılarının turizm endüstrisinde etkisi olduğunu ve bunun küresel ölçekte gerçekleştiğini ifade etmektedir. Aynı zamanda katılımcılar genellikle terör saldırılarının istihdamı azalttığını belirtmektedir.

Ekonomik kriz olgusunun turizm endüstrisi üzerindeki etkisi, Tablo 2'ye göre incelendiğinde, katılımcıların tamamının ülkelerin ekonomik durumlarını olumsuz etkilediğini belirttiği görülmektedir. Katılımcıların çoğunluğu, ekonomik krizlerin turizm endüstrisindeki istihdamı ve hizmet kalitesini olumsuz yönde etkilediğini ifade etmiştir.

Katılımcıların terör ve ekonomik kriz olgularının turizm üzerindeki etkisine ilişkin çeşitli ifadeleri;

- “Terör de ekonomik kriz de turizmi olumsuz etkiler. Terör saldırıları olduğunda insanlar güven ve endişe sorunu yaşamaktadır. Risk almak istememektedir. Can güvenliği olmadığı bir yere seyahat etmek istememektedirler (K15)."

- "Küresel olarak terör saldırıları turizm endüstrisini mutlaka etkileyecektir (K2)."

- “Ekonomik kriz de turizmi etkilemektedir. Çünkü finansal piyasalarda yaşanan krizler ülkeleri çöküşe sürüklemektedir. Böylece turizme hizmet verebilecek işletmeler finansal anlamda sıkıntı yaşarlar. Devamlı değişmesi yenilenmesi gereken ve insanlara farklılık sunması gereken 
turizm endüstrisinde bu bahsedilenler gerçekleşmediğinde insanların tercihi dişında kalır (K10)."

Katılımcıların görüşleri genel olarak değerlendirildiğinde, turizm endüstrisinin ekonomik krizlerden ve terör saldırılarından farklı açılardan olumsuz bir şekilde etkilendiği görülmektedir. Ayrıca, katılımcilara göre, her iki olgunun benzer şekilde turizm endüstrisinde hem istihdama hem de yatırımlara olumsuz yansıdığı ortaya çıkmıştır.

\section{Eylül 2001 Saldırıları ve 2008 Ekonomik Kriz Sonucunda Küresel Ölçekte Etkilenen Endüstriler}

Terör saldırıları ve ekonomik krizler bağlamında küresel çapta etkilenmenin yaşandığı en önemli olaylardan biri terör açısından 11 Eylül 2001 saldırıları; ekonomik açıdan ise 2008 küresel ekonomik krizi olarak bilinmektedir. Bu bağlamda, küresel çapta etkilenen endüstrileri ortaya çıarmak amaciyla Tablo 3 oluşturulmuştur.

Tablo 3. 11 Eylül 2001 Saldırıları ve 2008 Ekonomik Kriz Sonucunda Küresel Ölçekte Etkilenen Endüstrilere İlişkin Görüşler

\begin{tabular}{|c|c|c|c|c|c|}
\hline \multicolumn{3}{|c|}{11 Eylül 2001 Terör Saldırıları } & \multicolumn{3}{|c|}{2008 Ekonomik Kriz } \\
\hline 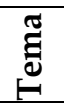 & Kodlama & Kodların Sıklığ & $\underset{\tilde{g}}{\tilde{E}}$ & Kodlama & $\begin{array}{l}\text { Kodların } \\
\text { Sıklığı }\end{array}$ \\
\hline \multirow{8}{*}{ 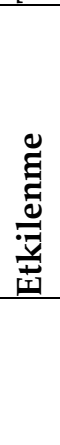 } & Havayolu Sektörü & 30 & \multirow{7}{*}{ 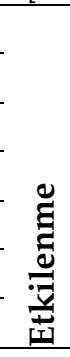 } & Uluslararası Ticaret & 25 \\
\hline & Diş Ticaret & 5 & & Bankacılık Sektörü & 28 \\
\hline & Konaklama Sektörü & 25 & & Turizm Endüstrisi & 30 \\
\hline & Eğlence Sektörü & 10 & & Havayolu Sektörü & 15 \\
\hline & Yiyecek-İçecek Sektörü & 18 & & Otomotiv & 5 \\
\hline & Turizm Endüstrisi & 30 & & Emlak & 30 \\
\hline & Güvenlik Endişesi & 25 & & Ulaşım Sektörü & 15 \\
\hline & Rezervasyon İptalleri & 30 & \multirow{4}{*}{ 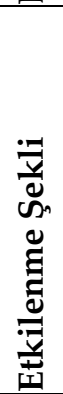 } & $\begin{array}{l}\text { İşletmelerin Küçülmeye } \\
\text { Gitmesi }\end{array}$ & 15 \\
\hline \multirow{3}{*}{ 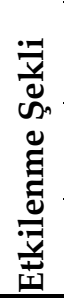 } & $\begin{array}{l}\text { Maliyet Planlamalarının } \\
\text { Olumsuz Etkilenmesi }\end{array}$ & 10 & & $\begin{array}{l}\text { Turistlerin Gelirlerinde } \\
\text { Düşüşler }\end{array}$ & 20 \\
\hline & $\begin{array}{l}\text { Uluslararası Ticaretin } \\
\text { Olumsuz Etkilenmesi }\end{array}$ & 13 & & İşsizliğin Artması & 20 \\
\hline & İstihdam Sorunu & 20 & & $\begin{array}{l}\text { Ekonomik } \\
\text { Azalmasi }\end{array}$ & 18 \\
\hline
\end{tabular}

Tablo 3'e göre katılımcıların 11 Eylül 2001 saldırıları ve 2008 Ekonomik Krizi sonucunda küresel ölçekte etkilenen endüstrileri değerlendirdikleri görülmektedir. Buna göre, katılımcıların büyük bir çoğunluğu, 11 Eylül terör saldırılarının etkilerinin havayolu, eğlence, yiyecek-içecek gibi sektörlerde diğer bir deyişle turizm endüstrisi üzerinde etkisi olduğunu belirtmektedir. Ayrıca, katılımcıların yine çoğunluğu, 11 Eylül terör saldırılarının bu endüstrilere olan etkisinin rezervasyon iptalleri ve güvenlik endişesine neden olduğunu, diğer bir kısmı da istihdama olumsuz etkisinin olduğunu ifade etmiştir.

Katılımcıların tamamı 2008 Ekonomik Krizi'nin emlak ve turizm endüstrisi üzerinde etkisi olduğunu belirtmektedir. Bununla birlikte, katılımcıların yoğun olarak 2008 Ekonomik Krizi'nin 
turizm endüstrisini turist gelirlerindeki düşüşler ve işsizliğin artması şeklinde etkilediğini vurgulamıştır.

Katılımcıların 11 Eylül 2001 saldırıları ve 2008 ekonomik kriz sonucunda küresel ölçekte etkilenen endüstrilere ilişkin çeşitli ifadeleri;

- "11 Eylül saldırıları en çok havayolları etkilenmiştir. Bunun temel nedeni saldırıların uçakla yapılmış olmasıdır. Turistlerin uçağa binmekten tedirgin olmasının sonucu konaklama işletmeleri de boş kalmıştır (K12)."

- "11 Eylül saldırılarında sonra havayolları dolayısıyla konaklama işletmeleri boş kaldı. Daha önce alınan rezervasyonlar iptal edildi. İptaller olunca işletmelerin daha önceden aldığı ürün veya hizmet giderleri çevrilemedi (K20)."

- "2008 krizi birçok eğitim, ulaşım gibi birçok endüstriyi etkilemiştir. Ekonomik krizlerden her zamanki gibi kitlesel açıdan hareket eden turistler de etkilenmiştir (K11)."

- "2008 krizinin başlama nedenine bakıldığında emlak, bankacılık ile ilgili olmasından dolayı uluslararası ticaret de etkilenmiştir (K5)."

Katılımcıların görüşleri, 11 Eylül 2001 terör saldırıları ve 2008 Ekonomik Krizi'nin benzer olarak havayolu sektörünü ve buna bağlı olarak turizm endüstrisini etkilediği yönünde olduğu görülmektedir. Tablo 3'te, 11 Eylül terör saldırıları ile birlikte 2008 Ekonomik Krizi'nin endüstrilere yansımasının istihdam sorunu, bir diğer deyişle işsizliğin artması şeklinde tespit edilmektedir.

\section{Eylül 2001 Terör Saldırıları ve 2008 Ekonomik Krizi'nin Küresel Sonuçları}

11 Eylül 2001 terör saldırıları ve 2008 Ekonomik Krizi'nin küresel olarak sonuçlarını ortaya çıararak ekonomik, politik, sosyo-kültürel ve benzeri açlardan irdelemek gerekmektedir. Bu bağlamda, 11 Eylül 2001 saldırıları ve 2008 Ekonomik Krizi'nin küresel olarak sonuçlarının yer aldığı Tablo 4 oluşturulmuştur.

Tablo 4. 11 Eylül 2001 Terör Saldırıları ve 2008 Ekonomik Krizi'nin Küresel Sonuçlarına İlişkin Görüşler

\begin{tabular}{|c|c|c|c|c|c|}
\hline \multicolumn{2}{|c|}{11 Eylül 2001 Terör Saldırıları } & \multicolumn{3}{|c|}{2008 Ekonomik Kriz } & \multirow[b]{2}{*}{$\begin{array}{c}\text { Kodların } \\
\text { Siklığı }\end{array}$} \\
\hline 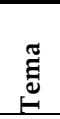 & Kodlama & $\begin{array}{c}\text { Kodların } \\
\text { Sıklığı }\end{array}$ & $\underset{\Xi}{\tilde{d}}$ & Kodlama & \\
\hline \multirow{4}{*}{ 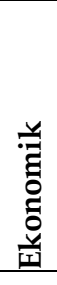 } & Maliyetlerin Artması & 20 & \multirow{7}{*}{ 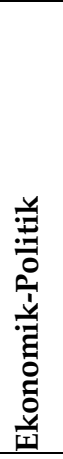 } & İşsizliğin Artması & 18 \\
\hline & Ekonomik Politikaların Değişmesi & 13 & & Ekonomik Durgunluk & 23 \\
\hline & $\begin{array}{l}\text { Uluslararas1 } \quad \text { Ticaret } \\
\text { Zayıflama }\end{array}$ & 15 & & $\begin{array}{l}\text { Banka Kredi İmkanlarının } \\
\text { Olumsuz Yönde Değişmesi }\end{array}$ & 18 \\
\hline & Finansal Piyasalardaki Değişimler & 8 & & & \\
\hline \multirow{3}{*}{$\begin{array}{l}\breve{y} \\
: 0 \\
0\end{array}$} & Din Temelinde Ayrımcılık & 10 & & & \\
\hline & $\begin{array}{l}\text { Havaalanlarındaki Uygulamaların } \\
\text { Arttırılması }\end{array}$ & 18 & & & \\
\hline & Dış Politikada Değişiklikler & 5 & & & \\
\hline \multirow{3}{*}{ 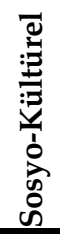 } & Din Temelinde Ayrımcılık & 8 & \multirow{3}{*}{ 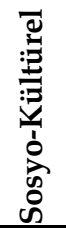 } & $\begin{array}{lr}\text { Ekonomik Buhran Sonucu } \\
\text { Kültürel } & \text { Faaliyetlerin } \\
\text { Olumsuz Etkilenmesi }\end{array}$ & 23 \\
\hline & İnsanların Şaşkın ve Endişeli Olması & 15 & & Sosyal Hakların Kısıtlanması & 13 \\
\hline & İnsanların Güvenlik İhtiyacı Duyması & 23 & & Suç Oranlarında Artış & 5 \\
\hline
\end{tabular}


Tablo 4'e bakıldığında, katılımcıların, 11 Eylül 2001 terör saldırıları ve 2008 Ekonomik Krizi'nin küresel sonuçlarına ilişkin değerlendirmeleri görülmektedir. 11 Eylül 2001 terör saldırılarının küresel sonuçları, katılımcıların belirttikleri görüşler doğrultusunda ekonomik, politik ve sosyokültürel temaları oluşturularak ifade edilmektedir. Katılımcıların çoğunluğu, ekonomik açıdan, 11 Eylül 2001 saldırılarının küresel sonucuna ilişkin maliyet artışına vurgu yapmıştır.

11 Eylül 2001 saldırılarının küresel sonuçları değerlendirildiğinde, politik olarak, katılımcıların çoğu havaalanlarındaki uygulamaların arttırılması gerektiğini vurgulamaktadır. Aynı zamanda, 11 Eylül 2001 saldırılarının küresel sonuçlarının birinin de katılımcıların çoğunluğu tarafından sosyo-kültürel açıdan insanların güvenlik ihtiyacı duyması olarak vurgulamıştır.

Katılımcı görüşleri incelendiğinde, 2008 Ekonomik Krizi küresel sonuçlarının politik (siyasi) olarak daha çok ekonomi politikaları şeklinde olduğu tespit edilmiştir. Bu bağlamda, kodlama yapılırken iki temanın birbirinden ayrılamamış olması nedeniyle tema 'ekonomik-politik' olarak belirlenmiştir. Bu durum terör saldırısından ekonomik krizi ayıran en önemli özellik olarak ortaya çıkmaktadır. Bu bağlamda, 2008 Ekonomik Krizi küresel sonuçları değerlendirildiğinde, ekonomik-politik açıdan katılımcılar çoğunlukla ekonomik durgunluğun ortaya çıktığını vurgulamaktadır.

Katılımcıların 11 Eylül 2001 saldırıları ve 2008 Ekonomik Krizi'nin küresel sonuçlarına ilişkin çeşitli ifadeleri;

- “11 Eylül 2001 saldırılarının ardından tüm dünya korkuya kapıldı. ABD’de böyle bir saldırının olması her yerde olabileceği endişesi doğurdu (K6)."

- "11 Eylül saldırılarının küresel sonuçları olmuş, ekonomik daralma, kısırlaşan ticari ve sosyal ilişkiler, küresel çapta ülkelerarası güvensizlik, değişen güvenlik algısı ve konsepti ilk akla gelen sonuçlardır (K13)."

- "2008 ekonomik krizinin sonucunda ekonominin kötü olması kişilerin seyahate çıkmalarını veya diğer eğlence, dinlenme vb. amaçlı yapılacak her şeyi engellemiş. (K11)".

- "Ekonomide durgunluk yaşanmış, banka kredilerinde sıkıntı olmuş ve belirli miktarlarda krediler alınabilmiş veya alınamamıştır (K30)."

\section{Eylül Terör Saldırıları ve 2008 Ekonomik Krizi'nin Turizm Endüstrisine Yönelik Sonuçları}

11 Eylül 2001 terör saldırılarının ve 2008 Ekonomik Krizi'nin turizm endüstrisine yansıyan sonuçlarını ortaya çıkarmak gerekmektedir. Ayrıca, bu saldırı ve krizlere benzer durumların yeniden ortaya çıkabilme ihtimaline ilişkin turizm endüstrisinde dikkate alınması gereken noktaların belirlenmesi için Tablo 5 oluşturulmuştur.

Tablo 5'e bakıldığında, 11 Eylül 2001 terör saldırılarının turizm endüstrisine yansıyan sonuçlarını, katılımcıların belirttikleri görüşler doğrultusunda ekonomik, politik, sosyo-kültürel, etkilenme ve etkilenme hizmet türü temaları oluşturularak belirtilmektedir. Katılımcıların tamamı, ekonomik açıdan, turizmden elde edilen gelirlerin düştügünü ve turizm talebinin azaldığını vurgulamıştır.

11 Eylül terör saldırılarının politik açıdan turizm endüstrisine yönelik sonuçlarını katılımcıların bir kısmı güvenlik tedbirlerinin yeniden gözden geçirilmesi olarak değerlendirmiştir. Bununla birlikte, katılımcıların çoğu tarafından, bu saldırıların turizm endüstrisine sosyo-kültürel açıdan sonuçlarının turist tercihlerinin değişmesi ve turist hassasiyetinin artması olduğu vurgulanmıştır. 
Tablo 5. 11 Eylül Terör Saldırıları ve 2008 Ekonomik Krizi'nin Turizm Endüstrisine Yönelik Sonuçlarına İlişkin Görüşler

\begin{tabular}{|c|c|c|c|c|c|}
\hline \multicolumn{3}{|c|}{11 Eylül 2001 Terör Saldırıları } & \multicolumn{3}{|c|}{2008 Ekonomik Kriz } \\
\hline$\underset{\mathscr{2}}{\mathscr{0}}$ & Kodlama & $\begin{array}{l}\text { Kodların } \\
\text { Sıklığı }\end{array}$ & 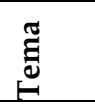 & Kodlama & $\begin{array}{l}\text { Kodların } \\
\text { Sıklığ1 }\end{array}$ \\
\hline \multirow[b]{7}{*}{ 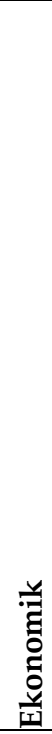 } & Turizme Olan Talep Azalmıştır. & 30 & \multirow[b]{7}{*}{ 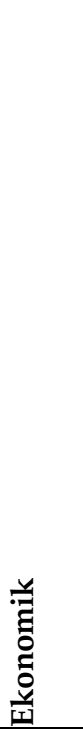 } & $\begin{array}{l}\text { Turizm } \\
\text { Talebinin Düşmesi } \\
\end{array}$ & 25 \\
\hline & $\begin{array}{l}\text { Ülkeler İçin Turizmden Elde Edilen } \\
\text { Gelir Düşüşüu }\end{array}$ & 30 & & $\begin{array}{l}\text { Turizm } \\
\text { Gelirinin Düşmesi }\end{array}$ & 30 \\
\hline & $\begin{array}{l}\text { Turizm İşletmelerinin Olumsuz } \\
\text { Etkilenmesi }\end{array}$ & 20 & & $\begin{array}{l}\text { Konaklama Hizmetleri ile } \\
\text { İlgili } \\
\text { Maliyetlerin Artması }\end{array}$ & 8 \\
\hline & $\begin{array}{l}\text { İstihdamın } \\
\text { Olumsuz Etkilenmesi }\end{array}$ & 20 & & $\begin{array}{ll}\text { Yiyecek-İçecek } & \text { Hizmetleri } \\
\text { ile İlgili } & \text { Maliyetlerin } \\
\text { Artması } & \\
\end{array}$ & 5 \\
\hline & Gelir Seviyesinin Düşmesi & 13 & & $\begin{array}{l}\text { Turizm Pazarlarındaki } \\
\text { İşsizlik Artmıştır }\end{array}$ & 23 \\
\hline & & & & $\begin{array}{lc}\text { Turizm } & \text { İşletmelerinin } \\
\text { Kredi İmkânın Azalması }\end{array}$ & 15 \\
\hline & & & & $\begin{array}{l}\text { Turizm İşletmelerinin } \\
\text { Harcamalarının } \\
\text { Kısıtlanması }\end{array}$ & 8 \\
\hline \multirow{9}{*}{ 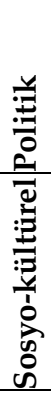 } & Güvenlik Tedbirlerinin Revize & 13 & \multirow{4}{*}{ : } & Turizm & 10 \\
\hline & Edilmesi & & & Teşviki Politikalarında & \\
\hline & Politik Açıdan Baskı & 8 & & Devlet & \\
\hline & Politik İstikrarsızlık & 5 & & Desteğinin Azalması & \\
\hline & $\begin{array}{lll}\text { Turizmin } & \text { Farklı } \quad \text { Kültürleri }\end{array}$ & 10 & & Turistlerin $\quad$ Harcama & 15 \\
\hline & Birleştirici Özelliği Vardır. & & \multirow{4}{*}{ 它: } & Eğilimlerinin Değişmesi & \\
\hline & Turist Hassasiyet Artışı & 18 & & Destinasyon Tercihleri & 13 \\
\hline & Suç Oranlarının Artması & 8 & & Değişmiştir. & \\
\hline & Turistlerin Tercihlerinin Değişmesi & 23 & & & \\
\hline \multirow{6}{*}{ 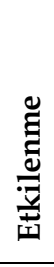 } & Havayolu İşletmeleri & 30 & \multirow{6}{*}{ 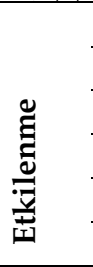 } & Havayolu İşletmeleri & 13 \\
\hline & Konaklama İşletmeleri & 25 & & Konaklama İşletmeleri & 25 \\
\hline & Tur Operatörleri & 10 & & Tur Operatörleri & 5 \\
\hline & Yiyecek-İçecek İşletmeleri & 13 & & Yiyecek-İçecek İşletmeleri & 13 \\
\hline & Seyahat Acentaları & 23 & & Seyahat Acentaları & 25 \\
\hline & Eğlence İşletmeleri & 8 & & Eğlence İşletmeleri & 5 \\
\hline \multirow{13}{*}{ 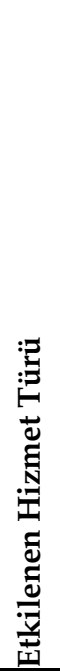 } & Konaklama & 25 & \multirow{13}{*}{ 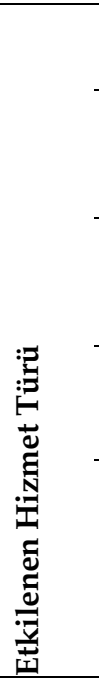 } & Konaklama & 25 \\
\hline & Rezervasyonlarının İptali & & & Rezervasyonlarının İptali & \\
\hline & Ulaştırma & 30 & & Ulaştırma İşletmeleri & 10 \\
\hline & Rezervasyonlarının & & & Rezervasyonlarının İptali & \\
\hline & Yiyecek-İçecek & 13 & & Yiyecek-İçecek İşletmeleri & 10 \\
\hline & $\begin{array}{l}\text { İşletmeleri } \quad \text { Rezervasyonlarının } \\
\text { İptali }\end{array}$ & & & Rezervasyonlarının İptali & \\
\hline & Acentalarının & 25 & & Seyahat Acentalarının & 25 \\
\hline & Rezervasyonlarının İptali & & & Rezervasyonlarının İptali & \\
\hline & Toplantı Turizmi $\quad$ Kapsaminda & 5 & & Rezervasyonların Azalması & 8 \\
\hline & Rezervasyonların İptali & & & & \\
\hline & Güvenlik Önlemlerinin Artması & 23 & & & \\
\hline & Rezervasyonların Azalması & 5 & & & \\
\hline & Eğlence Sektörünün Daralması & 8 & & & \\
\hline
\end{tabular}


11 Eylül terör saldırılarından turizm endüstrisinin nasıl etkilendiğini ifade eden Tablo 5'e göre katılımcıların tamamı havayolu işletmelerinin ciddi şekilde etkilendiğini belirtmiştir. Bununla birlikte katılımcıların çoğu, konaklama işletmelerinin ve seyahat acentalarının da 2001 terör saldırıları sonrasında turizmin önemli derece de etkilendiğini ifade etmiştir.

11 Eylül 2001 terör saldırılarının ardından turizm endüstrisinde etkilenen hizmet türü bakımından değerlendirildiğinde katılımcıların tamamı, ulaştırma işletmelerindeki rezervasyonların iptalini belirtmiştir. Bununla birlikte, katılımcıların çoğu terör saldırılarının bir sonucu olarak turizm endüstrisinde etkilenen diğer hizmet türleri arasında güvenlik önlemlerinin artması ile konaklama işletmeleri ve seyahat acentaları rezervasyonlarının iptalleri olduğu yönünde görüş bildirmiştir.

2008 Ekonomik Krizi'nin turizm endüstrisine yansıyan sonuçlarını, katılımcıların belirttikleri görüşler doğrultusunda ekonomik, politik, sosyo-kültürel, etkilenme ve etkilenme hizmet türü temaları oluşturularak Tablo 5'de gösterilmektedir. Katılımcıların tamamı, ekonomik açıdan, turizmden elde edilen gelirlerin düştüğünü vurgulamıştır.

2008 Ekonomik Krizi'nin turizm endüstrisine yansıyan sonuçları, katılımcıların yarısından daha az bir kısmı, politik açıdan, turizm teşvik politikalarında devlet desteğinin azaldığını belirtmiştir. Öte yandan, katılımcıların yarıdan fazlası, 2008 Ekonomik Krizi'nin turizm endüstrisine sosyokültürel olarak, turist harcama eğilimindeki değişiklik olduğunu vurgulamıştır.

2008 Ekonomik Krizi'nden turizm endüstrisinin nasıl etkilendiğini ifade eden Tablo 5'e göre katılımcıların tamamına yakını konaklama işletmeleri ve seyahat acentalarının etkilendiğini vurgulamıştır.

2008 Ekonomik Krizi'nin ardından turizm endüstrisinde etkilenen hizmet türü bakımından değerlendirildiğinde katılımcıların tamamına yakını, konaklama işletmeleri ve seyahat acentalarının rezervasyonların iptalini belirtmiştir.

Katılımcıların 11 Eylül 2001 saldırıları ve 2008 Ekonomik Krizi'nin turizm endüstrisine yönelik sonuçlarına ilişkin çeşitli ifadeleri;

- “Doğrudan turizm endüstrisine etkisi olmuştur. 11 Eylül saldırıları sonucunda otel işletmeleri ve havayolu işletmeleri derinden etkilenmiştir (K8)."

- "11 Eylül saldırılarının ilk sonuçlarından biri olarak güvenli ve rahat ulaşım aracı olarak kabul edilmeye başlanılan uçak yolculuklarının korkulur hale gelmesidir. (K7)."

- "Havayolu ulaşımında talep azalması ve maliyetlerin artması nedeniyle turizm ulaşım maliyeti de artmıştır (K9)."

- “2008 Ekonomik Krizi'nin önemli bir sonucu, genel olarak alım gücünün orta gelir gruplarında düşmesi ve yoğun olarak turizm talebinde bulunan bu grubun gelecek endişesiyle turizm harcamalarından vazgeçmesi olmuştur (K3)."

- “2008 ekonomik krizi sonucunda konaklama işletmeleri ve turist grupları için anlaşma yapan seyahat acentaları en çok etkilenmiştir. Seyahat acentaları turist gruplarının rezervasyonları iptal etmiş, böylece konaklama işletmelerine gidecek olan turistlerin rezervasyonları da iptal olmuştur. Ama bu durum sadece bu iki turizm alanındaki işletmeleri değil birbirine bağlı olarak diğer havayolu, eğlence, yiyecek içecek işletmeleri, tur operatörleri de etkilemiştir (K28)."

Katılımclar, hem 11 Eylül hem de 2008 Ekonomik Krizi sonucunda turizm endüstrisinin etkilendiğini belirtmişlerdir. Bu bağlamda, her iki olgunun da turizm endüstrisi içerisinde yer alan bütün işletmeleri ve turistleri; gelir, talep, maliyet, güvenlik vb. açılardan etkileyerek rezervasyon iptallerine neden olduğu görülmektedir. 
Katılımcıların görüşleri doğrultusunda 11 Eylül saldırıları ve 2008 Ekonomik Krizi ile ilgili etki, sonuç vb. açlardan her iki olgunun benzerlik ve farklılıklarına dair Tablo 6 ve Tablo 7 oluşturulmuştur.

Tablo 6. Benzerlik Tablosu

\begin{tabular}{l}
\hline 11 Eylül 2001 Terör Saldırıları / 2008 Ekonomik Krizi \\
\hline Küresel Ölçekte Turizm Endüstrisini Etkilemesi \\
\hline Küresel Ölçekte İşsizliğin Artması \\
\hline Turizm Gelirlerinin Düşmesi \\
\hline Turizm Olan Talebin Azalması \\
\hline Turizme Olan Yatırımların Azalması \\
\hline Küresel Ölçekte Maliyetlerin Artması / Ekonomik Durgunluk \\
\hline Turizm Pazarlarında İşsizlik / İstihdam Sorunu \\
\hline Turizm Endüstrisinde Maliyetlerin Artması \\
\hline Turizm Endüstrisindeki Rezervasyon İptalleri \\
\hline Konaklama İşletmeleri, Yiyecek-İçecek İşletmeleri, Havayolu İşletmeleri, Seyahat Acentaları, \\
Tur Operatörleri, Eğlence İşletmelerinin Etkilenmesi \\
\hline
\end{tabular}

Tablo 6'ya göre 11 Eylül 2001 saldırıları ve 2008 Ekonomik Krizi sonucunda, turizm endüstrisinin işsizliğin artması, talep azalması, yatırımların azalması vb. açılardan etkilenmesi yönünden benzerlik gösterdiği tespit edilmiştir. Ayrıca, her iki olgunun da küresel ölçekte işsizlik, ekonomik durgunluk vb. konularda sonuçlar ve etkiler doğurduğu bir diğer benzer yönleridir. Ayrıca, Tablo 6' da bu saldırı ve ekonomik kriz sonucunda, turizm endüstrisi zincirinde yer alan konaklama, yiyecek-içecek, havayolu, seyahat acentaları, eğlence vb. işletmelerinin etkilenmesi ve etkilenen hizmet türünün rezervasyon iptalleri şeklinde ortaya çıkması yönüyle de benzerlikleri olduğu görülmektedir.

Tablo 7. Farklilıklar Tablosu

\begin{tabular}{|c|c|}
\hline 11 Eylül 2001 Terör Saldırıları & 2008 Ekonomik Krizi \\
\hline $\begin{array}{l}\text { Küresel ölçekte en çok etkilenen; havayolu ve } \\
\text { konaklama işletmeleri }\end{array}$ & $\begin{array}{l}\text { Küresel ölçekte en çok etkilenen; emlak, bankacılık ve } \\
\text { uluslararası ticaret }\end{array}$ \\
\hline $\begin{array}{l}\text { Küresel ölçekte endüstrilerde en çok güvenlik } \\
\text { endişesi VE rezervasyon iptali şeklinde kendini } \\
\text { göstermiştir. }\end{array}$ & $\begin{array}{l}\text { Küresel ölçekte endüstrilerde en çok turist } \\
\text { gelirlerinde düşüş ve işletmelerin küçülmeye gitmesi } \\
\text { şeklinde kendini göstermiştir. }\end{array}$ \\
\hline $\begin{array}{l}\text { Turizm endüstrisinde; en çok etkilenenler } \\
\text { sirasıyla havayolu işletmeleri, konaklama } \\
\text { işletmeleri ve seyahat acenteleri şeklinde } \\
\text { olmuştur. }\end{array}$ & $\begin{array}{l}\text { Turizm endüstrisinde; en çok etkilenen konaklama } \\
\text { işletmeleri ve seyahat acenteleri ayni seviyede } \\
\text { etkilenmiştir. }\end{array}$ \\
\hline $\begin{array}{l}\text { Turizm endüstrisinde en çok etkilenen hizmet } \\
\text { türü sırasıyla; ulaştırma işletmeleri rezervasyon } \\
\text { iptali ve konaklama işletmeleri rezervasyon iptali } \\
\text { olmuştur. }\end{array}$ & $\begin{array}{l}\text { Turizm endüstrisinde en çok etkilenen hizmet türü; } \\
\text { konaklama işletmeleri ve seyahat acentelerinin } \\
\text { rezervasyon iptali şeklinde ortaya çıkmıştır. }\end{array}$ \\
\hline $\begin{array}{l}\text { Etkilenen hizmet türünde eğlence sektörü ve } \\
\text { toplantı turizmi kapsamında rezervasyon iptalleri } \\
\text { olmuştur. }\end{array}$ & $\begin{array}{l}\text { Turizm teşvik politikalarından devlet desteğinin } \\
\text { azalması yaşanmıştır. }\end{array}$ \\
\hline $\begin{array}{l}\text { Turizm endüstrisinde güvenlik tedbirlerinin } \\
\text { revize edilmiştir. }\end{array}$ & elerinin krec \\
\hline Politik baskı ve istikrarsızlık olmuştur. & Turist harcama eğilimlerinin değişme yaşanmıştır. \\
\hline orinin artmutr & \\
\hline
\end{tabular}


Tablo 7'ye göre 11 Eylül 2001 saldırılarından en çok havayolu ve konaklama işletmeleri etkilenirken 2008 Ekonomik Krizi sonucunda emlak, bankacilık ve uluslararası ticaret en çok etkilenmiştir. Bununla birlikte, 11 Eylül saldırıları sonucunda küresel ölçekte endüstriler en çok güvenlik endişesi ve rezervasyon iptali şeklinde ortaya çıkarken, 2008 Ekonomik Krizi'nin de bu durum turist gelirlerinde düşüş ve işletmelerin küçülmeye gitmesi şeklinde kendini gösterdiği saptanmıştır. Tablo 7'ye göre, 2008 ekonomik Krizi sonucunda turizm teşvik politikalarında devlet desteğinin azaldığı ve turist harcama eğilimlerinin değiştiği görülmektedir.

11 Eylül saldıılarının ardından ise politik baskı ve istikrarsızlık, turist hassasiyetlerinin artması şeklinde etki ve sonuçların ortaya çıktığı Tablo 7'de görülmektedir. Bununla birlikte, Tablo 7'ye göre, 11 Eylül saldırıları turizm endüstrisini ilk olarak ulaştırma işletmelerini ve sonrasında konaklama işletmelerini; 2008 Ekonomik Krizi'nin ise konaklama ve seyahat acentalarını etkilemiştir.

\section{SONUÇLAR ve ÖNERILER}

Günümüzde sert güçten öte, cazip yönlerini kullanarak amaçlara ulaşmayı hedefleyen ülkeler için önemli bir unsur olarak yumuşak güç ön plana çımıştır. Uluslararası ölçekte bireylerin rahat, huzurlu, güvenli seyahat etmesini isteyen ülkeler, yumuşak güç aracı kabul ettiğimiz turizme odaklanarak kolay bir şekilde bu ortamı sağlayabilmektedirler. Bu olumlu yönlerine karşın dünya ölçeğinde gerçekleşen terör ve yaşanan ekonomik krizler turizm taleplerinin dramatik düşüşüne sebebiyet vermektedir.

Terör saldırıları ve ekonomik krizlerin önemli ölçüde turizm endüstrisindeki istihdamı etkilediği görülmektedir. Bununla birlikte, terör faaliyetlerinin turizm talebini büyük oranda ekonomik, sosyal, siyasi, psikolojik vb. olarak çok boyutlu olarak etkilediği ve etkilerinin de küresel ölçekte gerçekleştiği saptanmıştır. Ayrıca, ekonomik krizlerle birlikte ülke ekonomilerinin gerilemesiyle turizm gelirlerinde yaşanan düşüş turizm endüstrisindeki hizmet kalitesinin düşmesine ve turizme yapılan yatırımların da azalmasına neden olduğu tespit edilmiştir. 11 Eylül saldırılarının sonucunda turizm gelirleri, turist sayıları, bireylerin psikolojisi, güvenlik problemleri, maliyet planlaması, uluslararası ticaret hacmi vb. faaliyetlerin düşmesine neden olmuştur. 11 Eylül saldırılarının en çok havayolu sektörünü, daha sonra konaklama sektörünü etkilediği çalışma sonucunda ortaya çıkmıştır. Bu saldırıların turizm endüstrisindeki sonuçları en çok rezervasyon iptalleri şeklinde ortaya çıkmıştır.

2008 Ekonomik Krizi, 11 Eylül 2001 saldırılarında olduğu gibi, turizm endüstrisini ekonomik, sosyal, kültürel, psikolojik, politik, siyasi vb. açıdan farklı şekillerde etkilediği tespit edilmiştir. 2008 Ekonomik Krizi sonucunda, emlak ve bankacılık sektörüyle birlikte uluslararası ticaretin de düşüşe geçtiği, seyahat hareketlerinin yavaşladığı ortaya çıkmıştır. Ayrıca, rezervasyon iptalleriyle ulaşım sektörü ile özellikle havayolu sektörünün ekonomisini zayıflatmıştır. 2008 Ekonomik Krizi turizm endüstrisinde, gelirlerin düşmesi, turistlerin harcama eğilimlerinin azalması, işsizliğin artması, ekonomik refahın düşmesi ve işletmelerin küçülmesinde de rol oynadığı anlaşılmıştır.

11 Eylül 2001 terör saldırılarının turizm üzerine olan etkileri arasında talep düşüklüğü sonucu turizmden elde edilen gelirin azalması olarak ifade edilebilir. Bu bağlamda, saldırıların turizm işletmelerinin iş hacmini zayıflattığı, işsizlik oranını arttırdığ 1 ve böylece turizm çalışanlarının gelir seviyelerini düşürdüğü tespit edilmiştir. 2008 Ekonomik Krizi'nin endüstrisi üzerindeki ekonomik etkileri ise, 11 Eylül 2001 saldırıları ile benzer bir şekilde turizm talebinin ve turizm gelirlerinin düşmesi, turizm pazarlarında işsizliğin ve turizm işletmeleri maliyetlerin artması olarak saptanmıştır. 
11 Eylül terör saldırılarının ekonomik sonucu olarak maliyetlerin artması, uluslararası ticarette düşüşler yaşandığı ve ekonomi politikalarının değiştiği görülmüştür. 2001 terör saldırılarının politik sonuçları olarak ise özgürlük güvenlik dengesinde özgürlükler aleyhine tedbirlerin artırıldığı görülmüştür. Saldırıların sosyo-ekonomik sonuçları ile ilgili ise; insanların daha tereddütlü, şaşkın ve endişeli hissiyatlar taşıdıklarının yanı sıra suç oranlarında artış olduğu saptanmıştır. Ayrıca, hem 11 Eylül saldırıları hem de 2008 Ekonomik Krizi sonrası turistlerin destinasyon tercihlerinde yaşanan değişim bu olaylarının turizmi sosyal- kültürel etkilerinden bir diğeri olmuştur.

11 Eylül saldırıları ile benzer olarak 2008 Ekonomik Krizi sonrasında havayolu, konaklama, tur operatörleri, yiyecek-içecek, seyahat acentaları ve eğlence işletmelerinin faaliyetlerinin yavaşladığı, rezervasyon iptalleriyle karşı karşıya kaldığı ortaya çıkmıştır. Bununla birlikte, 11 Eylül saldırılardan farklı olarak, 2008 Ekonomik Krizi'nden en çok konaklama işletmeleri ile seyahat acentalarının etkilendiği görülmüştür. Ayrıca hem terör saldırıları hem de ekonomik krizin sonucunda, turizm işletmeleri arasında en fazla etkilenenlerin ise konaklama ve seyahat acentaları işletmeleri olduğu sonucuna varılmıştır.

Turizm endüstrisine devlet tarafından destek verilmesi ve geliştirilmesi uluslararası barışa da katkı sağlayacağından, devletlerin bu konuda gerekli tedbirleri almaları oldukça önem taşımaktadır. Devletlerin turizm ile ilgili plan ve politikalarını belirlerken öngörülemeyen terör ve ekonomik krizleri de göz önünde bulundurulmalıdır.

Turistler, siyasi, politik ve ekonomik açıdan karmaşanın olduğu ortamlardan uzaklaşmaktadır. $\mathrm{Bu}$ doğrultuda, bireylere, güvenliklerini tehlikeye atmadan ama teröre destek anlamına gelebilecek tercihlerden kaçınmaları önerilebilir. Ayrıca, ekonomik krize rağmen, turistlerin daha önceden belirledikleri turizm programlarından tamamen vazgeçme modeli yerine daha ucuz turistik planlamalar yapmaları veya daha tasarruflu tercihlerde bulunmaları önerilebilecek bir diğer husustur. Bunun dışında turizm işletmelerinin de ani gelişebilecek terör veya ekonomik krizleri hesaba katarak gerekli tedbirleri almaları önerilebilir.

\section{KAYNAKÇA}

Akbaş, Z. ve Tuna, H. (2012). Bir Dış Politika Aracı Olarak Yumuşak Gücün Turizm Sektörüne Etkisi: Türkiye Örneği Üzerinden Bir Değerlendirme. Finans Politik \& Ekonomik Yorumlar, 49 (571), $5-17$.

Akturan, U. (2013). Nitel Araştırmalarda Örnekleme. (Editör) Baş, T. ve Akturan, U.). Nitel Araştırma Yöntemleri NVivo ile Nitel Veri Analizi, Örnekleme, Analiz, Yorum içinde (ss.195-203). Ankara: Seçkin Yayıncllık.

Almuedo, A. (2011). New Turkish Foreign Policy Towards The Middle East: Neither So New Nor So Turkish. PapersIEMed/EuroMesco. European Institute of the Mediterranean (IEMED), Barcelona, No. 4.

Apak, S. (2009). 1929 ve 2008 Krizlerinin Karşılaştırılması: Dünya ve Türkiye Örneği. Muhasebe ve Finansman Dergisi, 41, 6-16.

Aydemir, E. (2005). Uluslararası Krizlerde Kriz İletişimi ve Uygulaması. Sosyal ve Ekonomik Araştırmalar Dergisi, 10, 205-231.

Aziz, A. (2011). Sosyal Bilimlerde Araştırma Yöntemleri ve Teknikleri. (6. Basım), Ankara: Nobel Akademik Yayıncılık. 
Blake, A. and Sinclair, M.T. (2003). Tourism Crisis Management US Response to September 11. Annals of Tourism Research, 30 (4), 813-832.

Cavlek, N. (2002). Tour Operators and Destination Safety. Annals of Tourism Research, 29 (2), 478 496.

Chen, Y. and Duggan, N. (2016). Soft Power and Tourism: A Study of Chinese Outbound Tourism to Africa. Journal of China and International Relations, 4(1), 45-66.

CNN U.S. (2001). September 11: chronology of terror. http://edition.cnn.com/2001/US/09/11/chronology.attack/ .

Creswel, J.W. (2007). Qualitative Inquiry \& Esearch Design Choosing Among Five Approach. USA: Sage Publications.

Çavuş, T. (2012). Dış Politika da Yumuşak Güç Kavramı ve Türkiye'nin Yumuşak Güç Kullanımı. Kahramanmaraş Sütçü İmam Üniversitesi İktisadi ve İdari Bilimler Dergisi, 2 (2), 23-36

Dahl, R. A. (1957). The Concept of Power. Behavioral Sciences, 2(3), 201-215.

Durgun, A. (2010). Ekonomik Krizlerin Turizm Sektörüne Etkileri 2008 Ekonomik Krizinin Antalya Konaklama İşletmelerine Etkilerinin Analizi, Yayınlanmamış Doktora Tezi. Süleyman Demirel Üniversitesi, Isparta.

Günal, A. (2004). Büyük Ortadoğu Projesi ve Türkiye. Ege Akademik Bakış Dergisi, 4 (1), 156-164.

Gür, N. (2014). Yeni Türkiye'nin Yumuşak Güç Unsuru: Turizm. Seta Perspektif, 58, 1-5.

Hall, C.M. (2010). Crisis Events in Tourism: Subjects of Crisis in Tourism. Current Issues in Tourism, 13(5), 401-417.

IATA (2009). Annual Report 2009 65th Annual General Meeting, Canada: IATA.

IMF (2010). The IMF-FSB early warning exercise. https://www.imf.org/external/np/pp/eng/2010/090110.pdf.

Kadercan, B. (2014). Güç. (Editör) Kardeş, Ş. ve Balcı, A. : Uluslararası İlişkilere Giriş: Tarih Teori, Kavram ve Konular içinde (ss.311-322) İstanbul: Küre Yayınları.

Kadığlu, B. (2010). 2008 Ekonomik Krizi, Yayınlanmamış Yüksek Lisans Tezi. Abant İzzet Baysal Üniversitesi, Bolu.

Kaplan, E.A. ve Dayığlu, M.R. (2017). Ekonominin Sırtındaki Yük: Terör. Uluslararası Sosyal Araştırmalar Dergisi, 10 (49), 623-636.

Karaatlı, M., Demiral, M.F., Zeynel, E. ve Pala, Y. (2009). Küresel krizinin KOBİ'lerde yarattı̆̆ 1 etkiler ve kriz yönetimi: Göller Bölgesi örneği. Süleyman Demirel Üniversitesi Sosyal Bilimler Enstitüsü Dergisi, 2 (10). 143-161.

Kutlu, R. (2010). Uluslararası Terörizm Ve 11 Eylül Sonrasında Türkiye'nin Terörizmle Mücadelesi, Yayınlanmamış Yüksek Lisans Tezi. Karadeniz Teknik Üniversitesi, Trabzon.

Mor, B. D. (2006). Public Diplomacy in Grand Strategy. Foreign Policy Analysis, 2(2), 157-176.

Mutlu, Ç. ve Akbaş, Z. (2016). 11 Eylül Saldırıları Üzerinden Uluslararası Terörün Turizme Etkisi: Türkiye Örneği. Düzce Üniversitesi Sosyal Bilimler Enstitüsü Dergisi, 6 (2), 1-14.

Nanto, D.K. (2001). 9/11 Terrorism: Global Economic Costs (RS 21937). Congressional Research Service, 2-6.

Nye, J.S. (2004). Soft Power: The Means To Success In World Politics. (First Edition), United States of 
Public Affairs: New York.

Ooi, C. (2015). Soft power, tourism. In Jafari, J. and H. Xiao (Eds.). Encyclopedia of Tourism, Springer. https://www.researchgate.net/publication/302544078.

Papatheodorou, A., Rossello, J. and Honggen, X. (2010). Global Economic Crisis And Tourism: Consequences And Perspectives. Journal of Travel Research, 49(1), 39-45.

Pforr, C. and Hosie, P.J. (2008). Crisis management in Tourism, Journal of Travel \& Tourism Marketing, 23 (2-4), 249-264.

Pizam, A. (2009). The Global Financial Crisis and its impact on the Hospitality Industry. International Journal of Hospitality Management, 28 (3), 301.

Roux-Dufort, C. (2007). Is Crisis Management (only) a Management of Exceptions. Journal of Contingencies and Crisis Management, 15 (2), 105-114.

Pusti, M. (2013). Krizlerin Anatomisi ve Türkiye'de 2001-2008 Finansal-Ekonomik Krizleri Üzerine Bir Inceleme, Yayınlanmamış Yüksek Lisans Tezi, Atılım Üniversitesi, Ankara.

Sever, M. ve Kılıç, E. (2001). Düşmanını Arayan Savaş. (1. Baskı). İstanbul: Everest Yayınları.

Smeral, E. (2011). How international tourism is coping with the consequences of the financial and economic crises. In P. Keller and T. Bieger (Eds.). Tourism Development After the Crises: Global Imbalances - Poverty Alleviation. Berlin: Erich Schmidt Verlag.

Unur, K. (2000). Turizm-Terörizm İlişkisi ve Türkiye Örneği. Anatolia: Turizm Araştırmaları Dergisi, 11(2), 169-177.

UN (2009). Outcome of The Conference On The World Financial and Economic Crisis and its Impact on Development. Sixty-third Session, General Assembly, Resolution No 63/303.

UN Security Council (2001). Security Council Resolution 1368 of 12 September 2001. http://www.un.org/Docs/scres/2001/sc2001.htm.

UNWTO (2001). Tourism After 11 September 2001: Analysis, Remedial Actions and Prospects: Travel and Tourism Recovery. Madrid: Committee, Special Report: 18.

UNWTO (2010). World Tourism Barometer: on Track For Recovery After an Exceptionally Challenging 2009. January 2010, 8 (1), Madrid: World Tourism Organization. https://www.eunwto.org/action/showPublications?category=10.1555\%2Fcategory.40000037\&p bType=bookOnly\&pageSize=20\&startPage=1. (Erişim tarihi: 15 Mayıs 2019).

UNWTO (2000). Tourism Highlights, 2000 Edition, Madrid: World Tourism Organization, https://www.e-unwto.org/action/showPublications?category=10.1555\%2Fcategory.40000037\&p bType=bookOnly\&pageSize=20\&startPage=1(Erişim tarihi: 15 Mayıs 2019).

UNWTO (2001). Tourism Highlights, 2001 Edition, Madrid: World Tourism Organization, https://www.e-unwto.org/action/showPublications?category=10.1555\%2Fcategory.40000037\&p bType=bookOnly\&pageSize=20\&startPage $=1$ (Erişim tarihi: 15 Mayıs 2019).

UNWTO (2002). Tourism Highlights, 2002 Edition, Madrid: World Tourism Organization, https://www.e-unwto.org/action/showPublications?category=10.1555\%2Fcategory.40000037\&p bType=bookOnly\&pageSize=20\&startPage=1(Erişim tarihi: 15 Mayıs 2019).

UNWTO (2003). Tourism Highlights, 2003 Edition, Madrid: World Tourism Organization, https://www.e-unwto.org/action/showPublications?category=10.1555\%2Fcategory.40000037\&p bType=booknly\&pageSize=20\&startPage=1(Erişim tarihi: 15 Mayıs 2019). 
UNWTO (2004). Tourism Highlights, 2004 Edition, Madrid: World Tourism Organization, https://www.e-unwto.org/action/showPublications?category=10.1555\%2Fcategory.40000037\&p bType=booknly\&pageSize=20\&startPage=1(Erişim tarihi: 15 Mayıs 2019).

UNWTO (2005). Tourism Highlights, 2005 Edition, Madrid: World Tourism Organization, https://www.e-unwto.org/action/showPublications?category=10.1555\%2Fcategory.40000037\&p bType=bookOnly\&pageSize=20\&startPage=1(Erişim tarihi: 15 Mayıs 2019).

UNWTO (2006). Tourism Highlights, 2006 Edition, Madrid: World Tourism Organization, https://www.e-unwto.org/action/showPublications?category=10.1555\%2Fcategory.40000037\&p bType=bookOnly\&pageSize=20\&startPage=1. (Erişim tarihi: 15 Mayıs 2019).

UNWTO (2007). Tourism Highlights, 2007 Edition, Madrid: World Tourism Organization, https://www.e-unwto.org/action/showPublications?category=10.1555\%2Fcategory.40000037\&p bType=bookOnly\&pageSize=20\&startPage=1. (Erişim tarihi: 15 Mayıs 2019).

UNWTO (2008). Tourism Highlights, 2008 Edition, Madrid: World Tourism Organization, https://www.e-unwto.org/action/showPublications?category=10.1555\%2Fcategory.40000037\&p bType=bookOnly\&pageSize=20\&startPage=1. (Erişim tarihi: 15 Mayıs 2019).

UNWTO (2009). Tourism Highlights, 2009 Edition, Madrid: World Tourism Organization, https://www.e-unwto.org/action/showPublications?category=10.1555\%2Fcategory.40000037\&p bType $=$ bookOnly\&pageSize $=20 \&$ startPage $=1$. (Erişim tarihi: 15 Mayıs 2019).

UNWTO (2010). Tourism Highlights, 2010 Edition, Madrid: World Tourism Organization, https://www.e-unwto.org/action/showPublications?category=10.1555\%2Fcategory.40000037\&p bType $=$ bookOnly\&pageSize $=20 \&$ startPage $=1$. (Erişim tarihi: 15 Mayıs 2019).

UNWTO (2011). Tourism Highlights, 2011 Edition, Madrid: World Tourism Organization, https://www.e-unwto.org/action/showPublications?category=10.1555\%2Fcategory.40000037\&p bType $=$ bookOnly\&pageSize $=20 \&$ startPage $=1$. (Erişim tarihi: 15 Mayıs 2019).

UNWTO (2012). Tourism Highlights, 2012 Edition, Madrid: World Tourism Organization, https://www.e-unwto.org/action/showPublications?category=10.1555\%2Fcategory.40000037\&p bType=bookOnly\&pageSize=20\&startPage $=1$. (Erişim tarihi: 15 Mayıs 2019).

UNWTO (2013). Tourism Highlights, 2013 Edition, Madrid: World Tourism Organization, https://www.e-unwto.org/action/showPublications?category=10.1555\%2Fcategory.40000037\&p bType=bookOnly\&pageSize=20\&startPage=1. (Erişim tarihi: 15 Mayıs 2019).

UNWTO (2014). Tourism Highlights, 2014 Edition, Madrid: World Tourism Organization, https://www.e-unwto.org/action/showPublications?category=10.1555\%2Fcategory.40000037\&p bType=bookOnly\&pageSize=20\&startPage=1. (Erişim tarihi: 15 Mayıs 2019).

UNWTO (2015). Tourism Highlights, 2015 Edition, Madrid: World Tourism Organization, https://www.e-unwto.org/action/showPublications?category=10.1555\%2Fcategory.40000037\&p bType=bookOnly\&pageSize=20\&startPage=1. (Erişim tarihi: 15 Mayıs 2019).

UNWTO (2016). Tourism Highlights, 2016 Edition, Madrid:World Tourism Organization, https://www.e-unwto.org/action/showPublications?category=10.1555\%2Fcategory.40000037\&p bType=bookOnly\&pageSize=20\&startPage=1. (Erişim tarihi: 15 Mayıs 2019).

UNWTO (2017). Tourism Highlights, 2017 Edition, Madrid: World Tourism Organization, https://www.e-unwto.org/action/showPublications?category=10.1555\%2Fcategory.40000037\&p bType=bookOnly\&pageSize=20\&startPage=1. (Erişim tarihi: 15 Mayıs 2019).

UNWTO (2018). Tourism Highlights, 2018 Edition, Madrid: World Tourism Organization, https://www.e-unwto.org/action/showPublications?category=10.1555\%2Fcategory.40000037\&p 
bType $=$ bookOnly\&pageSize=20\&startPage=1. (Erişim tarihi: 15 Mayıs 2019).

Ündücü, C.A. (2011). Uluslararası Sistem ve Terörizm Arasındaki İlişki. Elektronik Siyaset Bilimi Araştırmaları Dergisi, 2 (1), 1-20. http://asosindex.com/cache/articles/20141-1.pdf.

Yıldız, Z. ve Durgun, A. (2010). 2008 Küresel Ekonomik Krizi Ve Turizm Sektörü Üzerine Etkileri. Süleyman Demirel Üniversitesi Vizyoner Dergisi, 2 (1), 1-15.

Yıldırım, S. (2010). 2008 Yılı Küresel Ekonomi Krizinin Dünya ve Türkiye Ekonomisine Etkileri. Karamanoğlu Mehmetbey Üniversitesi Sosyal ve Ekonomik Araştırmalar Dergisi, 12 (18), 47-55. 